\title{
DisZiPLingeSCHICHTE
}

\section{The Sovietisation of Hungarian Geography, 1945-1960}

Róbert GYŐRI, Budapest, and Ferenc GYURIS, Budapest/Heidelberg*

\section{Contents}

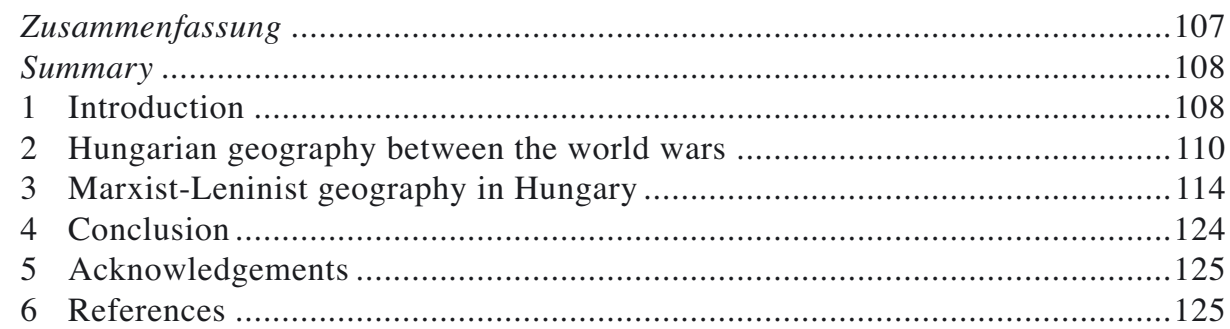

\section{Zusammenfassung}

Die Sowjetisierung der ungarischen Geographie, 1945-1960

Angesichts der enormen territorialen Verluste Ungarns nach dem Ersten Weltkrieg hat die politische Elite Ungarns die Geographie als wichtiges Instrument für die wissenschaftliche Begründung der Revision des Vertrags von Trianon betrachtet. Die Position der Disziplin wurde verstärkt, und die große Mehrheit der Geographen hat die politischen Ziele des Systems unterstützt. Nach der Besetzung Ungarns durch sowjetische Truppen im Jahr 1945 und der erzwungenen Einrichtung des kommunistischen Systems wurde die ungarische Geographie als „Diener der Regime in der Zwischenkriegszeit" für schuldig befunden. Die alte „reaktionäre“ und „,bourgeoise“ Geographie wurde beseitigt und nach sowjetischem Vorbild eine neue, marxistischleninistische errichtet. Letztere beruhte auf dem Konzept des ökonomischen Determinismus und die „physische“ und „ökonomische“ Geographie wurden radikal getrennt. Die Disziplin war nun Diener des kommunistischen Systems und Teil der

\footnotetext{
* Dr. Róbert GYőRI, Department of Social and Economic Geography, Eötvös Loránd University, Pázmány Péter sétány 1/C, H-1117 Budapest; email: gyorirobert@caesar.elte.hu, http://geogr.elte.hu/;

Ferenc GyURIS, Department of Regional Science, Eötvös Loránd University, Pázmány Péter sétány 1/C, H-1117 Budapest; Institute of Geography, Ruprecht Karls University, Berliner Straße 48, D-69120 Heidelberg; email: gyurisf@gmail.com, http://geogr.elte.hu/; http://www.geog.uni-heidelberg.de/
} 
nationalen Wirtschaftsplanung. Staatliche Forschungsinstitute, die zur Akademie der Wissenschaften gehörenden Institute und das Zentrale Planungsbüro dienten nun als die wichtigsten ,centres of calculation“, in denen nach sowjetischem Vorbild „, große Wissenschaft“ (big science) betrieben wurde. Zahlreiche „alte“ Geographen wurden pensioniert oder aus dem akademischen Leben verbannt. Andere wurden an den Rand gedrängt oder gezwungen, mit dem neuen System Kompromisse zu schließen. Sie wurden ersetzt durch politisch vertrauenswürdige „Neulinge“, die alle wichtigen Positionen bekamen. Die internationale Orientierung der ungarischen Geographie wurde einem radikalen Wandel unterzogen. Der ehemals starke Einfluss der deutschen und französischen Geographie wurde zurückgedrängt und durch eine stabile Orientierung auf die „befreundeten“ Sozialistischen Länder, besonders auf die UdSSR, ersetzt.

\section{Summary}

Following Hungary's serious losses of territory after World War I, geography became regarded as a major tool for the scientific substantiation of claims to territorial revision by the political elite. The discipline's position was strengthened, and the vast majority of geographers supported the political goals of the regime. After 1945, however, Hungary became a part of the Soviet occupation zone. After the violent establishment of the Communist system, geography was found guilty of having served the interwar political regime. The old 'reactionary' and 'bourgeois' geography was demolished and a new, Marxist-Leninist geography on Soviet principles was established. The latter was based on the concept of economic determinism: 'physical' and 'economic'geography were strongly distinguished. Geography became a part of national economic planning. State research institutes and those of the Academy of Sciences, and the Central Planning Office became the most important 'centres of calculation' where Soviet-type 'big science' was established. Several 'old' geographers were pensioned off or exiled from academia; others were driven to the periphery or forced to compromise with the system. In the meanwhile, all important positions were given to politically loyal 'newcomers'. The international orientation of Hungarian geography changed as well: former German and French influence was followed by a stable orientation towards 'friendly' Socialist countries, especially towards the USSR.

\section{Introduction}

"We should state clearly that no Marxist economic geographer wishes to »locate « the old, reactionary, capitalism-serving human geography, neither some nor any of its branches in Marxist economic geography. It is no aim at all to rename the child. There are some unscrupulous people, who, proceeding from an erroneous theoretical foundation, are afraid that we are throwing out the baby with the bath water. For my opinion, we should just throw out the child." (MARKos 1955, p. 365) 
When we came across the term and concept of postcolonialism for the first time, we were convinced that this approach has merely anything to add to Hungarian geography and to its history as Hungary is a small landlocked country in East Central Europe: Neither has it ever had a colonial empire, nor was it exposed to colonisation. As we have reconsidered the issue, however, a blurred image got outlined, suggesting that the postcolonial approach can help us in a better understanding of two phases in Hungarian geography.

Between 1867 and 1918, Hungary was part of the Austro-Hungarian Monarchy together with Austria, part of an empire that had the greatest territorial extension in Europe. Hungarian geography was not untouched by this imperial context. Rezső HAVASS, the vice-president of the Hungarian Geographical Society in the early $20^{\text {th }}$ century, was considered an 'enthusiastic and determined champion of Hungarian imperialism' by his contemporaries (HAJDÚ 2007, p. 17), but HAVASS's plans for the economic and political colonisation of the Balkans were never realised. The Austro-Hungarian Empire ended in 1918 and with it Hungarian imperial desires. On the eve of World War II, Hungary became a part of the German sphere of influence, and after 1945, of the Soviet Union's. The Soviet occupation of East Central Europe can be seen as imperialism. For David Chioni Moore, the American scholar of Lithuanian descent, the greatest deficiency of postcolonial literary criticism is that it has neglected the Sovietisation of Eastern Europe (CHIONI MoORE 2001). Following the approach of SAID (1993), Ashcroft, Griffiths \& Tiffin (1998), and McEwan (2009), it would be more precise in the case of post-Socialist countries such as Hungary to speak about Soviet imperialism instead of Soviet colonialism as the criteria for the latter one (a Soviet administration 'established in situ' and large-scale settlements from the Soviet empire) are not fulfilled. In this sense, the term 'Soviet colonialism' could only refer to the post-Soviet republics. As these two expressions are usually used interchangeably in the relating literature, however, and as we consistently use the term 'colonialism', we use the term in this paper.

For Moore, here are parallels between 'Western' colonialism in the Sub-Saharan Africa and the Soviet's in East Central Europe: Indigenous governments are replaced with puppet control or outright rule; education is revamped to privilege the coloniser's language; histories (and geographies), and curricula are rewritten from the imperium's perspective; autochthonous religious traditions are suppressed, and alternative religions and nonreligious ideologies are promoted; the colonies become economic fiefdoms with economic production undertaken on a command basis and trade permissible only through the empire's alliance network (CHIONI Moore 2001, p. 114).

In post-war Hungary, all these phenomena could be easily identified: Most of them are well documented. But scholarship on the history and geography of science is silent on the intellectual transformation of the 1950s and 1960s. The narratives put an emphasis on the creation of continuities with the preceding decades (and thus, on implicit self-legitimacy) instead of detecting break points and applying a postcolonial analytical framework. For instance, AnTAL (2006) tries to 'harmonise' three Hungarian geographers' generally different points of view in order to produce a continuity between 'old Hungarian economic geography' and Marxist-Leninist economic geography, and to legitimise the latter approach through 'big names' (GYŐRI 2009). In the meanwhile, 
concerning the connection between the Communist era and the recent one, the narratives' argumentation is quite similar to that of the former 'Western' colonial powers, trying to situate the strongly disputable events of the colonial times 'in the past to make us think it is now over and done with' (KAPOOR 2004, p. 630).

The last two decades have witnessed numerous articles dealing with the former Socialist region and, particularly, the issue of 'transition'. In an overview of these researches, STENNING and HöRSCHELMANN argue that the theoretical framework of such works should adopt a post-Socialist point of view. For them, understanding the geography of the region should also not ignore those questions concerning knowledge as "a form of power, and by implication violence" (McEwAn 2009, p. 26) and of representation played in the practice of Soviet domination (STEnNing \& Hörschelmann 2008).

This paper contributes to the better understanding of these issues by revealing how Hungarian geography was colonised during the 1950s, how the Communist system crushed 'the old geography' in order to establish the Hungarian Marxist-Leninist geography. We describe different epistemological cultures that influenced and determined the approaches, methods, social tasks and the educational role of Hungarian geography between the world wars and after World War II. We analyse the effect that MarxistLeninist ideology exerted on Soviet geography in this period. Further, we investigate how a colonising ideology dominated Hungarian geography, how the institutional structure of geography was transformed, how the career paths of the 'old geographers' continued, and we outline who become 'new' geographers and how. Finally, we discuss how lasting this turn proved to be in Hungarian geography.

A main goal of our paper is to understand Socialist geographies and the colonised science's logic of functioning, but not to impose that this provides a 'universal' description of Soviet colonisation practices. It is also an aim to reveal that Marxist geography cannot only be a progressive, critical practice, but Marxist ideology could serve as the basis to a science serving an oppressive regime. The final aim of the paper is to help Hungarian geographers better understand the current state of Hungarian geography by tracing its Marxist-Leninist roots: The survival of these components is evidence for the post-Socialist state of Hungarian geography. We agree with STENNING and HöRSChelmann: Post-Socialism is an existing condition, which exists even after the end of the empire "because of the persistence of colonial forms, practices and legacies" (Stenning \& Hörschelmann 2008, p. 329).

\section{Hungarian geography between the world wars}

The dramatic changes occurring in Hungarian geography during the 1950s cannot be understood without knowledge about the discipline's role in Hungarian public thought and the academy before then. At the beginning of the $20^{\text {th }}$ century the so-called 'minority issue' was a source of internal tension in Hungary. In 1910, Hungarian was spoken as a native language by only a slight majority of the country's population: significant German, Romanian, Slovak, Serb and Rusyn communities were to be found on the 
peripheries. These minorities, dissatisfied with the Hungarian legal system and with national education and cultural policy, strove to get regional autonomy or to secede from Hungary. These views heightened during World War I, supported by the Triple Entente waging a war on the Austro-Hungarian Monarchy. Internal tensions together with foreign circumstances resulted in the fragmentation of Hungary: As a consequence of the 1920 Treaty of Trianon (Paris), the country surrendered two-thirds of its area and $60 \%$ of its population (and, also one-third of all native Hungarian speakers) to Romania, Czechoslovakia, the Kingdom of Serbs, Croats and Slovenes, and Austria (HAJdú 1998).

Hungarians were shocked by these territorial and population losses. The territorial revision of the peace treaty became a main goal of post-war governments in Hungary. Support was lent to disciplines that served revisionist aims and which promoted the strengthening of national identity. Geography - together with ethnography, history and statistics - held a privileged position among such disciplines.

Geographers had had a key role in Hungarian nation building before Trianon. The process of preparing for peace had produced a geographical monograph and a manifesto in several languages in order to inform foreign publics about Hungarian attitudes, produced under the aegis of the Hungarian Geographical Society. The chief organiser of this work was Pál TELEKI, a pioneer of Hungarian economic geography, who became a main negotiator of the Hungarian peace delegation in Paris, and, later on, Minister of Foreign Affairs and Prime Minister (HAJdú 2000). Geography ensured for itself the role of a 'competent science' at these peace negotiations, with numerous geographical experts participating in the treaty negotiations (Emmanuel DE MARTONNE from France, Isaiah Bowman from the United States, Alan G. OgiLvie from the United Kingdom, Jovan Cvisić from Serbia and the Polish Eugeniusz Romer) (Krasznai 2003). The majority of the Hungarian geographers contributing to the negotiations were to be appointed professor and head of department in the ensuing decade.

Although the peace talks failed to match Hungarian expectations, geography gained a reputation - in public eyes and in those of science and education policy. During the 1920 s, the institutional development of the discipline saw new departments and research institutes being opened. For instance, a new institute was established in order to process and evaluate the statistical material of the neighbouring countries (Államtudományi Intézet - Institute of Political Sciences), and another one to promote researches relating to Heimatkunde (homeland studies) (Táj- és Népkutató Központ - Region and Folk Research Centre). Secondary school reforms initiated in 1924 significantly increased the number of classes in geography, and, in 1925, the new elementary school curriculum included homeland studies in geographical education (FoDOR 1951). Geography also had an important role in other forms of youth education: geographers were to be found among the leaders of the scout movement, and books on national geography, history and culture were published.

In order to illustrate the role of the geographer in those times we have chosen the scientific and political career of Pál TELEKI (1879-1941). His career path reflects the intertwoven nature of geography and national politics during the first decades of the $20^{\text {th }}$ century. TELEKI, who began his work on the history of cartography, became inter- 
ested in French géographie humaine in the 1910s, when he was a member of parliament. During the 1920s and 1930s, he was the head of the Department of Economic Geography at the Faculty of Economics; the superintendent of Eötvös Collegium, a leading institution of national elite education established according to the principles of École Normale Superieure in Paris; and was Chief Scout of the Hungarian Scout Movement. TeleKI was appointed minister (first Minister of Religion and Education, then second Minister of Foreign Affairs), and became Prime Minister for the second time in 1938 (holding this position until 1941) (ABLONCZY 2007). In TelekI's career, the revisionary goals of Hungarian foreign politics, national identity and geographical research were strongly intertwined.

Given the privileged position of geography as a discipline, the vast majority of the geographers allied themselves to the 'official' conservative-national ideology of the era and internalised the political goals of the regime. Hungarian geographers dismissed or ignored those left-wing movements criticising the overall social and institutional order of the country and the state, as was evident in the clash of Hungarian geography with the 'village exploring movement' and with 'folk writers'. ('Folk writers' were young social scientists, 'sociographers' [novelists involved in sociology], who were trying to draw the nation's attention to the problems of the rural poor. In their works, they usually gave a 'sociographic' overview of a given region or village and identified the harsh nature of the estate system, and the peasants' defencelessness against landowners and state administration as the main cause for their poverty.) The reviewers of Földrajzi Közlemények (Geographical Review, the journal of the Hungarian Geographical Society) strongly criticised such 'sociographic' volumes, chastising equally their ideals and their weak science. In turn, the 'folk writers' condemned the insensitivity of geographers wrapped up in the formalities of their profession.

During the second half of the $19^{\text {th }}$ century, two major traditions of Hungarian geography were to be distinguished: nation-building and the geography of 'imperial aspirations'. While the former aimed to strengthen national identity, the latter (mainly represented by the Hungarian Geographical Society) manifested itself in the propagation of geographical discoveries, the support of Hungarian expeditions and the promotion of a rhetoric of Hungarian colonisation. Of special interest was the Balkans ('our Orient'), which was regarded as a main field for Hungarian economic expansion (HAJDÚ 2007). The horizon of Hungarian geography dramatically narrowed, however, after World War I. Thereafter, the French géographie humaine focusing on regional syntheses became accepted as the main paradigm.

The traditions of géographie humaine had to compete with the presence in Hungarian geography of German work in the later $19^{\text {th }}$ century, and the dominance of geomorphology during the last decade of the century. German geography still played a dominant role in Hungary between the world wars: almost $60 \%$ of the literature reviewed in Földrajzi Közlemények in this period was German, while only $13 \%$ was French and $11 \%$ English (GYŐRI 2001). The principles of géographie humaine became established after 1910 because of Pál TeleKI's activity, its acquisition due to his role and the place of geography during the peace talks, since TELEKI and his associates consciously based their argumentation on the terminology of this approach. They were aware that the French delegation was especially to be made convinced about the truth of Hungarian 
geographical concepts. Using their weapon against them seemed the best strategy to legitimise Hungarian arguments. They eagerly referred to the regional unity of the Carpathian Basin as an argument for maintaining a Greater Hungary: Although the country is linguistically divided, it is a landscape with remarkable physical geographical boundaries (it is almost identical to the drainage system of the central section of the River Danube and its tributaries), and, in an economic-geographical sense, it is a functional unity of interdependent and complementary regions, culturally unified with other regions. Hungarian geography did not diverge from these concepts in the following decades - a fact explaining the conscious insistence of Hungarian geography on VIDAL's (basically environmental) concept of region between the world wars (VIDAL DE la Blache became the most cited person in the manifesto of the Hungarian Geographical Society [KraszNaI 2003]).

The interwar period witnessed the 'golden age' of regional geography in accord with national political goals. Almost all monographs on the geography of Hungary focused on the geography of Greater Hungary as geographers sought to emphasise that the borders set by the Treaty of Trianon were temporary ones. As Ferenc Fodor wrote in his 1924 book concerning the economic geography of Hungary: "Describing the economic geography of 'Truncated Hungary' is per se a contradiction" (Fodor 1924, p. 9). Distinguishing the geographical regions of the country meant drawing up the macroregions of Greater Hungary. Maps depicting different views of regionalisation had a common point: Macroregions were split by the new borders, frequently down the middle (GYŐRI 2007). For Hungary's interwar geographers, the new borders of the country did not coincide with any physical, social or economic boundaries: they were the result of an arbitrary decision forced on the country. Even physical form was made to reflect this political moment. Gyula PRINZ, a respected geologist and geographer, published his Tisia concept on the tectonic development of the Carpathian Basin in 1926, and, in a revised form, ten years later. The purely tectonic model, according to which author tectonism had 'folded up' the Carpathian Mountains, was used to delineate the physical boundaries of a unitary country (KEMÉNYFI 2006).

At the same time, everyday life was infiltrated by geographical discourse much strongly than ever before. The defence of national space was basically a geographical issue. Geographical symbols appeared in schoolbooks, newspapers, speeches, operettas and songs of the period. (It was popular, for example, to christen new streets and squares after cities, mountains and rivers of the lost territories.) The best-known emblem of the period might well be the map depicting the borders after the Treaty of Trianon (Paris) within those of the Greater Hungary, with the text in the margin: 'Nem, nem, soha!' ['No, no, never!']. Not only did geography infiltrate revisionist discourse, revisionist rhetoric was also geographical.

The Hungarian revisionist foreign policy managed to reach some decisive success, but not earlier than the late 1930s (on the eve of the war, actually): By the First Vienna Award in 1938, the southern strip of Czechoslovakia was ceded to Hungary, while the Second Vienna Award in 1940 compelled Romania to cede Northern Transylvania [Transilvania] to Hungary. The results of peaceful revision, based on the arbitration courts' decisions, were supplemented in 1941 by some southern regions gained with military force from Yugoslavia (HAJdú 1998). Such territorial expansion was a na- 
tional success as was the success of Hungarian geography. Hungary had to pay a high price for these achievements, however, the country was more and more obligated to the Axis powers and the pressure on Hungary to enter the war was also growing. In consequence, German troops were allowed to deploy through Hungary to the Yugoslavian border in April 1941. Pál Teleki, having been in his second period of office as Prime Minister since 1939, and having signed a 'Treaty of Eternal Friendship' with the Kingdom of Yugoslavia in 1940, eventually committed suicide. Two months later, Hungary declared war on the Soviet Union. World War II left the country in ruins. The German army occupied Hungary in the spring of 1944, a fascist government serving the interests of the Nazi Germany was formed that autumn. Nationalist geography in Hungary did not support fascism: Because geographers evaded fascist movements, and rejected the 'scientific' arguments of German geopolitics.

\section{Marxist-Leninist geography in Hungary}

After 1945, Hungary became a part of the Soviet occupation zone. A brief provisional period with multi-party elections between 1945 and 1948 was followed by the violent establishment of the Communist regime. This event marked a radical turning point not only in the history of the country, but in the social sciences too - especially for geography. The 'colonisation' of geography was carried out in several ways. The purpose and aims for geography were reconceptualised, Marxist-Leninist ideology became mandatory in research practice. In institutions, the personnel changed.

As the Soviet pressure got strengthened, their reckoning with Hungarian fascism was followed by the reckoning with the whole of conservative-bourgeois Hungary. It was Erzsébet ANDics, a leading ideologist of the new system, who stated that Hungary had been a fascist state not only in the last year of the war but during the 1920s and 1930s as well (ANDICs 1945). This view referred also to the geography's place within the former regime. Attempts at territorial revision were identified as the main factors for entering the war, and against the scientific background of revision (and revisionist propaganda), the whole of geographical science was found guilty. It speaks volumes for the discipline's rapidly-weakening position that even TELEKI, whose political activity was still regarded with acclaim in 1945, soon appeared on the list of 'fascist war criminals' (ABLONCZY 2007).

\subsection{The example to follow: Marxist-Leninist geography in the Soviet Union}

The Russian Revolution of 1917 , which put an end to the Tsarist regime, was a significant milestone in Russian and world history. The political changes manifested in the rise of the Bolsheviks also marked the beginning of a new era in science. Geography was no exception: Instead of the old 'bourgeois' geography, a new Marxist-Leninist geography emerged. In order to understand Hungary's position in these terms, it is 
helpful to evaluate the political and economic circumstances of the early Communist regime with respect to geography.

The first event that gave momentum to the formation of 'Marxist geography' was less theoretical than practical in nature. Lenin's aim was to revitalise the country's economy after the war and to transform it from a small-peasant economy through largescale industrialisation (LENIN 1966). In his opinion, electrification was a necessary precondition to the realisation of this goal. This led to the creation of the GOELRO (Gosudarstvennaya Komissiya pa Elektrifikatsii Rossii - State Commission for Electrification of Russia), the first general economic/industrialisation plan of the Soviet economy (HoRvátH 2008). The successful realisation of this project also necessitated the establishment of the economic rayons, the spatial units of economic planning (RADó 1957a). As the work on GOELRO and the creation of economic rayons developed and involved numerous Russian geographers, these projects played a key role in the formation of Marxist geography (RADÓ 1957b).

Establishment of theoretical matters lagged far behind practical work. The first definition of the 'fundamental object' of the Marxist economic geography was given by Nikolay BARANSKIY in his book Economic Geography of the U.S.S.R., first published in 1926. In his approach, the task of the discipline was "to study the distribution and spatial combination of the productive forces, i.e., of the main factors that are required for production - the means of production, as well as the men themselves with their production experience and skill" (BARANSKIY 1956, p. 7). This was the first text to give insight into the concept of Marxist geography on the relationship of human and nature: Economic construction, which 'economic geography' should serve, is based not only "on fullest and strictest consideration of different natural conditions", it "is not confined merely to the utilization of natural resources; it simultaneously represents a radical transformation of nature" (BARANSKIY 1956, p. 8). BARANSKIY emphasises that the discipline is not aimed at passive understanding of the world, but at its radical transformation in building Socialism. "Economic geography of the U.S.S.R. is an active geography", involved in the "transformation of nature carried out [...] under the leadership of the Communist Party of the Soviet Union" (BARANSKIY 1956, p. 8).

Marxist-Leninist geography in the Soviet Union was basically propelled by the interests of bureaucratic planning. This led to a serious neglect of theoretical issues. Marxist-Leninist geography, brought into being by the need to solve highly-practical issues of planning, cannot be considered a 'natural' consequence of any prior existing Russian geographical traditions. The so-called 'branch-statistical' school of V. DeN in Saint Petersburg [Sankt-Peterburg], based on German bourgeois political economy and producing somewhat being "not more [...] than barren, formal, metaphysical economic statistics" (SAUSHKIN 1954, p. 96), could not be accepted by Marxist-Leninists. The other actors in Russian human geography were usually regarded as followers of Friedrich Ratzel, Alfred Hettner or Paul Vidal de la Blache (Radó 1957a; Saushin 1954; SAUSHKIN 1962) - a group lumped together as bourgeois by Soviet geographers as were blamed for the 'scientific substantiation' of the expansive politics in the 'imperialistic states' and for the defence of their ruling elites (Dobrov 1952). Even as 
creating coherent theoretical concepts was a big task for Marxist-Leninist geography, fragments of ideas began gradually to crystallise.

According to Marxist approaches, as (conscious) work is the factor making the difference between animals and humans, the foundation of society is production, and the characteristics of society are generally determined by the mode of production ("the method of producing the necessities of life"). Production itself is realised through the forces of production (or productive forces), "the forms in which nature and raw materials are appropriated and used in the labor process". Since "at a certain stage of their development, the productive forces come into conflict with the existing relations of production" (TIMÁR 2009, p. 214), revolutionary changes within society may mean that society enters a new phase of development. Marxism interprets the history of humankind as a process of linear development involving the phases of primitive Communism, slavery, feudalism, capitalism, Socialism and Communism. In closing down capitalism and giving way to Socialism (and to Communism in the long term), its main social aspect is the triumph of the proletariat, the exploited powerless class of the capitalist phase over the former elite, the bourgeoisie. This process is followed by the disestablishment of private ownership and the foundation of public ownership (Niedermaier 2009).

Marxist-Leninist geographers accepted MARX's opinion that "the most basic connection between society and nature [...] is production", and that production is a process through which human affects and changes the nature, while also changing its own nature through this (MARKos 1952, p. 271; MARX 1949, pp. 191-192). But, as STALIN, refining MARX, emphasised, "the change and development of society is incomparably faster than the change and development of nature" (STALIN 1950, pp. 648-649). The Marxist-Leninist point of view is, therefore, not that of geographical determinism but of economic determinism: the mode of production determines the kind of humannature relationship.

Given this, it is easier to understand the structure and terminology of MarxistLeninist (and, we would also add, Stalinist) geography. The economic determinism infusing the discipline and STALIN's concept about the different speed of natural and social development means that the two processes cannot follow the same regularities. Marxist-Leninist geographers denied the 'bourgeois' concept of geographical monism which - in their opinion - "tries to expand the effect and validity of natural rules to human society" (RADÓ 1962, p. 227), in order to provide scientific substantiation for the expansion and conquering wars of the 'imperialistic' (capitalist) states (DoBROV 1952). They instead distinguished 'two geographies', namely physical geography (a natural science investigating regularities in the development of geographical environment) and economic geography (a social science focusing on the rules determining the spatial allocation of population and production (GERAsimov 1959). Although it was emphasised that such a differentiation was not a discrete but a dialectical relation of the two 'geographies', this point was often ignored by Marxist-Leninist geographers in order to avoid any risks of being judged determinist, 'bourgeois' or 'reactionary'. The result was that cooperation between physical and economic geography became extremely weak by the mid 1950s. 


\subsection{The colonisation of Hungarian scientific life and the institutional transformation of geography}

The Soviet-type reorganisation of scientific life exerted a negative influence on the position of geography. As one evidence of transformation, 'important' scientific researches were removed from universities and concentrated into research institutes subordinate to the MTA (Magyar Tudományos Akadémia - Hungarian Academy of Sciences [HAS]). Within this new framework, the role of universities was to foremost as educational (teaching) bodies, while the personnel of academic institutes were free to devote their time to research. The Party's leading responsible for culture, György AcZÉL, interpreted this process in his 1980 retrospect thus: "At the end of the "forties we increased the number of students. Meanwhile, we extracted a significant part of the researchers with the best abilities, allocated them to research institutes so they could research undisturbed without the burden of teaching. In some cases we almost plundered universities ..."' (ACZÉL 1980, p. 170).

The task of the newly-established research institutes was laid down in the constitution of the academy: Priority to applied research which directly related to production. Science - an important force of production in Stalinist thought - became a part of national economic planning (or, to use the terminology of the era, 'people's economic planning'). The goals of science policy were presented in a chapter of five-year and annual economic plans, and synchronised with the economic and modernising aims of the political system. Emphasising applied research led also to a privileged position for natural and engineering science (especially for those disciplines serving the development of heavy industry or military strategic goals in a broader sense). Humanities were marginalised. Professional and administrative control of universities was put in the hands of HAS: Universities were debarred from awarding doctor's degrees, candidate of sciences and doctor of sciences degrees were issued by HAS, and scientific societies were also put under the superintendence of the Academy (PÉTERI 1998). (The Soviet-modelled candidate degree or CSc was a prerequisite for becoming a docens [reader] at universities, while the doctor of sciences degree or $D S c$ enabled one to be appointed as professor.)

In the Stalinised institutional system, state research institutes and those of the Academy, and the Central Planning Office founded in 1947 became the most important 'centres of calculation'. These were the new hot spots of science production, where Soviet-type 'big science' was established. Although geography in the United States had found its place within the new science as early as during World War II, and especially in the years after (BARNES 2006; BARNES \& FARISH 2006), this process began somewhat later in Hungary.

Thus stigmatised, geography fell from grace. The research institutes brought into being by TELEKI were disestablished or ideologically 'cleansed', with geographers belonging to the former staff being expelled. Geography remained without an independent research institute within the rapidly-organised institutional framework of the Academy. The geographical material of the former Államtudományi Intézet (Institute of Political Sciences) was handled by the Földrajzi Könyv- és Térképtár (Geographical 
Library and Map Archive) based on which the Geographical Research Group of the HAS was organised in 1951 - but only becoming an independent research institute in 1967 (as GRI HAS) (MARosi 2001).

At the same time the number of university departments decreased: At the University of Pécs the Faculty of Humanities was closed during the war and not reopened until 1992. This put an end to the history of Geographical Department there. (The number of geography departments and research institutions began to increase again during the 1960s, thanks to the proliferation of university departments, the establishment of teacher-training high schools and the strengthening position of GRI HAS.)

The heaviest casualty was the Hungarian Geographical Society, dissolved through a decree of the Ministry of the Interior in 1949. Its proscription was obviously motivated by the desire to quash 'reactionary' geography: "Circumstances seemed not to guarantee the development of the Society's work in a Marxist-Leninist spirit" (KocH 1952, p. 884). The disestablishment of the Society also saw the end of its journal Földrajzi Közlemények, published since 1872. Hungarian geography remained without a published forum for some years. (A new journal Földrajzi Értesító [Hungarian Geographical Bulletin] was launched by the Geographical Research Group of HAS in 1952 and, under a strong control, it became the leading journal of Hungarian geography later on.) The Society's activity was stopped until HAS, the organ for controlling science, initiated the retrieval of the ban by the Ministry of the Interior in 1952. Hungarian geography was assessed as having been integrated into the Soviet-type scientific system. The relating justification enumerates almost all steps of scientific colonisation: "... Hungarian geographers have made a big advance in the application of Marxist dialectic, have got to know the results of Soviet geographical science, and Hungarian geography has gained new Marxist cadres." (Косн 1952, p. 884).

\subsection{Old and new geographers in the 1950s}

The transformations affecting the whole discipline would not have been possible without changes in personnel. The staffing policy of the new system took various forms: Some geographers were pensioned off or exiled from academia; others were driven to the periphery so that they could keep their job, but not their former rank or position; some researchers were forced to compromise with the system (at least formally). All new appointments of the transformed institutional situation were filled by politically reliable figures, some of whom possessed neither a geographical education nor a university degree. Their involvement was crucial in helping realise the 'great ideological turn': Converting Marxist-Leninist principles into an unquestionable paradigm.

'Cleansings' which concerned geography began as early as 1945 . After the end of the war, assurance committees were established at each university and at each research institute in order to examine any possible activities by researchers in Hungarian fascism. There had been very few Hungarian geographers sympathising with fascism and none had participated in the fascist regime. Evaluation committees could thus hardly sanction anybody, although the adversities that TELEKI's direct colleagues had to overcome had a strong symbolic meaning. The political geographer András 
RónAI, who became the director of Institute of Political Sciences (the organisation coordinating scientific preparation for territorial revision) and the head of TelekI's department after the latter's death, was dismissed from his job. András RónAI (the vice-president of the Hungarian Geographical Society in those years) was employed in the National Széchényi Library before he was dismissed without a pension in 1949, aged 43 (DövÉNYi 2008).

The other professor of TELEKI's former department, the economic geographer Ferenc Fodor (who was appointed to corresponding fellow of HAS in 1944) left the University of Economics. FODOR later worked at home until his death, writing several manuscripts without any prospect of having them published (HAJDú 2006). Géza TELEKI, the son of Pál TELEKI, formerly a professor of geology at the University of Kolozsvár [Cluj-Napoca], later a lecturer of economic geography at his father's department and the Minister of Education of the Provisional Government after 1945, emigrated to the United States (Fodor 1951).

With the Communist party transforming the country more and more radically, geographers' prospects got progressively worse. In 1949, after the 'year of the turn', Communist science policy expelled all fellows of the Academy who did not 'fit' the new system. This 'cleansing', one step of the transformation of HAS, exerted a strong influence on social sciences overall. 54 percent of all fellows were expelled from the Academy; almost two-thirds of them were involved in humanities and social sciences, and a bit more than one-third in natural and applied sciences (PÉTERI 1998).

Geography suffered especially. All four geographers who were a fellow of the Academy (Jenő Cholnoky, Gyula Prinz, Béla Bulla and Tibor Mendöl) were expelled. The unequal fight between 'old' and 'new' geographers was manifested in several ways. The scientific work of most 'old regime' geographers was discussed (and evaluated negatively) from a Marxist-Leninist point of view (ANON 1954; MARKos 1955; AbelLA 1956; Косн 1956; АвеLla 1961). Members of the old regime staff were hindered from receiving newly-introduced Soviet-type scientific status, from having their articles and books published, and their student acolytes were expelled from universities.

The strategies of adaptation left few doors open for such 'old' geographers and whose they did, offered different possibilities for physical and human geographers. Although none of the old geographers became a supporter of the new system, acquiring and applying Marxist-Leninist ideology did present opportunities for physical and human geographers. Joining the Communist party could guarantee a kind of tranquillity (although no real intellectual freedom) and to reclaim given positions. The physical geographer Béla BuLLA - the only one among expelled geographers - was re-elected a fellow of the Academy in 1954, and, in the same year, became the president of the Geographical Society re-established in 1952 and the director of the newly-founded GRG HAS (Geographical Research Group of the Hungarian Academy of Sciences) (MARosi 2006). Bulla used his positions to act as a spokesperson of the 'old ones' and protect the former traditions and staff of Hungarian geography. The physical geographer László KÁDÁr, head of department at the University of Debrecen and a former disciple of TELEKI had published several articles and books on economic, political and urban geography early in his career. These works (and KÁDÁR himself) were exposed to the 
harsh opinion of György Markos, the main ideologist of the new regime. In the face of his criticism KÁDÁr turned to publishing more works in physical geography and to limit his research in human geography (SÜLI-ZAKAR 2008). In so doing, he could remain among the leaders of the University of Debrecen (he was dean before being appointed as chancellor), and he became the president of the Geographical Society in the late 1950 s.

Since their field of research was politically more sensitive, the possibilities for human geographers were more limited. The economic geographer Ferenc KocH, a disciple of TELEKI, compromised with the system - presumably to ensure his survival (Probáld 2001). KoCH - allegedly thanks to this 'flexibility' - was in 1952 appointed the first head of the newly-established Department of Regional Geography at the University of Budapest and the first director of GRG HAS. The urban geographer Tibor MENDöL could not, however, defend himself from attacks on him through his 'passive resistance'. MendöL, having been the head of Department of Human Geography at the University of Budapest since 1940, lost all his disciples and close colleagues as they were expelled from the university; he struggled to have his works published and to receive the doctor of sciences degree, the highest scientific rank in the Soviet-type academic system (GYóRI 2009). The fact that he also tried to reformulate his works along Marxist-Leninist principles in some of his works (MENDÖL 1954), was not enough. As one of his critics, who understood the main point of the work, remarked: "Nothing in this work allows Mendöl to say anything new from the aspect of urban geography, [he] just repeats his old approach in a new form" (ABELLA 1961, p. 124). Mendöl was made a doctor of science 'posthumously', one year after his death in 1966.

If such 'old regime' human geographers, even at the price of serious losses and unfair treatment, could retain some of their authority, the younger generation taught by them had almost no such prospects. Very few of MendöL's disciples avoided being totally displaced from geography (they managed to survive only in the peripheries). Their scientific creed and point of view on 'old' and 'new' geography was crucial. At the candidate defence of Edit LETTRICH, one of MENDÖL's disciples, critics and supporters merely concentrated on the content of the work but the relationship of Marxist-Leninist economic geography and 'bourgeois', 'reactionary' urban geography. The main sources of criticism were the candidate's supervisor himself (MENDÖL) and - absurdly - the subject of the article: Esztergom, the centre of the Hungarian Catholic Church. Finally, after a lengthy debate (notwithstanding the strongly dismissive opinion of one of the opponents, the MARKos disciple Zoltán ANTAL) the work was accepted (CZIRfusz 2010).

The leading ideologist of the 'new' geographers and a permanent actor of scientific debates was György MARKos, the initiator of Marxist-Leninist approach in Hungarian geography. MARKos had neither formal education in geography nor a university degree. He had, however, formerly had a significant role in the labour movement. As a student, he participated in the Hungarian Soviet Republic of 1919. Later on, he spent most of the interwar period as an émigré in the West, remaining as a member of the movement but working as a publicist and caricaturist. Before World War II he returned to Hungary where several newspaper articles by him were published, together 
with two populist works on economic history. During the war he was imprisoned for antifascist activity. After 1945 he worked at several jobs that were important for the Party (e.g. in the Central Planning Office) before being appointed head of Pál TELEKI's former department (renamed Department of Economic Geography) at Marx Károly University of Economics after the war and became the vice-president of the re-established Geographical Society in 1952 (TATAi 2004). MARKos, although he had had no prior connection with Hungarian geography, exerted authority rapidly: His articles applying Marxist-Leninist ideology to geography illustrated the new way not only for economic, but also for physical geographers. In debates, he confronted practically all leading geographers of the former epoch.

After a thorough changeover of staff, he shaped TELEKI's former department to become the leading workshop of Marxist-Leninist economic geography in Hungary; three heads of departments of the Socialist era began their scientific career under his aegis (BERNÁt 2004). MARKos's department soon became the most important 'truth spot' in Hungarian economic geography. The dissemination of the new knowledge was the task of MARKos's disciples, who, similarly to US 'space cadets' (BARNES 2004), began to work in leading centres of scientific life, or gained high positions in state apparatus after receiving their doctorates. (Many of them joined the Geographical Research Institute of the Academy, the Department of General Economic Geography at Eötvös Loránd University, the Scientific and Planning Institute of Urban Construction [VÁTI], the Central Planning Office and the College of Politics of Hungarian Socialist Workers' Party.) The essence of MARKos's life was succinctly summarised by one of his disciples in the special issue of Földrajzi Értesító, released for MARKos's retirement: "Markos was a revolutionary, a conscious and high standard Marxist in each situation" (ENYEDI 1968, p. 406). MARKos was a revolutionary indeed: His work exerted a considerable influence on the purpose of science, the theoretical framework for research and upon the lives of geographers, and led overall to thorough-going changes in Hungarian geography whose implications are still to be felt.

Perhaps an even more curious career was that of Sándor RADó, who succeeded MARKos as head of department after 1958. (MARKos was moved from the University of Economics after the Revolution of 1956; he could pursue his scientific work at the Academy's Geographical Research Institute.) As Markos, Sándor Radó played an active role in the international labour movement and, as a law student, had been a political officer of the Hungarian Red Army during the Hungarian Soviet Republic. After the downfall of the latter, he emigrated to Vienna [Wien], then to Germany, and finally to the Soviet Union, where he studied geography and gained a reputation as a cartographer (K. L. 1960), and, according to a CIA report, he was trained there for service with Soviet military intelligence (Thomas 1968).

Following some years in the USSR, he moved to Germany, then to Paris. From 1936, he lived in Geneva [Genève] until 1944, where he was a secret agent of Soviet intelligence under the umbrella of the news agency Geopress. (RADó wrote a biographical fiction about his service for the intelligence in the 1970s, which was brought to screen in his life.) In 1945, he was evacuated to the Soviet Union, where, since he was supposed to work for the British as well as a double agent, he was sentenced to ten 
years forced labour in 1946 (TRом 2006). He was not released before 1953, although according to US intelligence he spent only a short time in a Siberian coal mine (where he was a labour manager and thus not subject to hard physical work) before being shifted to a geographical observatory near Moscow [Moskva] as a 'prisoner with privileges' (the CIA assumed that Radó's shift and special treatment was the result of 'string-pulling by friends') (Thomas 1968).

RADÓ returned to Hungary in 1955 . He was appointed the leader of the national cartographic office (where, using his former international connections, he collected cartographic material from around the world with possible military-strategic relevance, a fact which concerned US intelligence [Thomas 1968]). He was the head of the Department of Economic Geography between 1958 and 1966, and became the president of the Hungarian Geographical Society in 1973. Besides receiving numerous prestigious Hungarian and Soviet awards he was elected honorary member of several geographical societies, honorary doctor of various universities and became a commission member of the International Geographical Union (PAPP-VÁRY 1998). RADó, latterly a scholar from having been a Communist adventurer, continued the work in economic geography begun by MARKos.

The era of jockeying for position in Hungarian geography ended before the mid1960s. The remaining 'old' geographers had by then retired or died, and few of their disciples or followers had continued their research issues. Although a kind of personal (as well as thematic) continuity could be revealed in physical geography between the interwar and Socialist epochs, human geography (that is, economic geography) was distinguished by interruption and break. From the 1960s, all important positions in Hungarian economic geography were dominated by 'newcomers' loyal to the system who regarded the 'old' Hungarian human geography as a reprehensible, outdated, bourgeois-reactionary science.

\subsection{The international relationship of Hungarian Marxist-Leninist geography}

The international nature of the discipline also underwent serious changes after the Communist 'turn' in 1948-49. Before the Soviet occupation of the country, German and French geographical thought exerted a major influence on Hungarian geographers. As noted, researches in physical geography were dominated by the geomorphological approach of the German Ferdinand von RichthofEN, while Hungarian human geographers followed the French concept of géographie humaine established by Paul VIDAL DE LA Blache and Jean BRUnhes.

These 'bourgeois' approaches were soon deemed unacceptable for Marxist-Leninist ideologists. Criticism of Western science became a general point of Marxist-Leninist scientific thought directed at all disciplines. Ernő GERő, the Minister of Finance and one of the three most influential Communist leaders of Hungary in that period was keen to emphasise this antibourgeois attitude, when he was elected head of the Hungarian Scientific Council (MTT), a new scientific institution. For GERő, "a serious mistake rather often made by our scientists and scientific researchers is servile courtesy before 
the West [...]. We have all reasons to weigh up and critically review what we receive from the West [...] and to deny automatically regarding it as the highest level of science" (GERŐ 1950, p. 345).

The goal of this reasoning, however, was not to create a kind of scientific autarchy in Hungary but to change the international orientation of Hungarian science. To cite GERó again: "The other serious mistake of our former scientific life [was] secluding ourselves from the East, from the socialist Soviet Union. [...] During the last three decades [...] [the USSR] has caught up with the most developed ones in the field of industries, agriculture, culture, arts and science as well. [...] It is time to draw the necessary inference from this issue" (Geró 1950, p. 346).

The implications of this international reorientation are closely mirrored by reviews and articles in Hungarian geographical journals. Important 'scientific raw material' in this respect is formed by the issues of Földrajzi Közlemények, the journal of the Hungarian Geographical Society. This geographical journal, the oldest one in Hungary, was regularly published between 1873 and 1944, and was relaunched in 1952. Given this long run, it enables us to conduct long-term analyses on the influence of foreign geographical achievements on Hungarian geographical thought.

Földrajzi Közlemények was not the only Hungarian journal concerning geographical questions, therefore it cannot perfectly represent the whole Hungarian geography, but it was the most important journal of the discipline before the Soviet occupation of the country, and remained significant after the advent of Communism, even when it had a rival in Földrajzi Értesitó, the journal of the newly-established Geographical Research Institute of the Hungarian Academy of Sciences.

A total of 1,077 pages of reviews were published in Földrajzi Közlemények between 1918 and $1944,48.1 \%$ of which referred to non-Hungarian literature. Reviewed foreign literature was obviously dominated by works in German $(59.1 \%$ of all reviewed foreign literature), followed by French (12.6\%) and English ones (11.2\%) (GYőRI 2001).

For the Communist period, analysis of the 603 reviews published in the journal between 1952 and 1989 reveal some major changes. The proportion of foreign works among reviewed ones only slightly increased compared to the interwar period (52.7\%). The relative weight of German literature dropped dramatically to $30.8 \%$ of all reviewed foreign works, while the French influence was stagnating (12.0\%). English language works gained much in significance $(25.2 \%)$, but the greatest increase was geographical literature in Russian $(20.1 \%$ ), a fact which heralded a 'new era' of 'scientific development', in association with the Communist regime.

The Soviet colonisation of Hungarian geography is even more apparent in examining the distribution of articles by nationality of author. Less than $7 \%$ of the 14,753 pages of articles published in Földrajzi Közlemények between 1952 and 1989 were written by foreign authors. In the 1950s (1952-59) a total of 253 pages was published in the journal from foreign researchers, of which total 228 were written by Soviet geographers. A further ten pages were the result of a Hungarian-Polish cooperation, while the West was represented by eleven pages in only one article under the title 'Geomorphology and Marxist thinking', written by the French tropical geomorphologist Jean TRICART. British and American and German articles were totally absent. 
These values were different in the 1960s: German publications reappeared (43 pages were written by German authors and a further 14 ones in German-Hungarian collaboration), and the proportion of Soviet articles dropped to $11.8 \%$ of all foreign articles compared to $90.1 \%$ in the 1950 s. General trends remained rather similar to the former decade in the sense that an overwhelming majority of the articles were written by experts of the Communist bloc (81.7\%): Although Soviet-authored articles totalled only thirty-one pages in this decade, Földrajzi Közlemények included Polish material (58 pages), Bulgarian (31), Czechoslovakian (31) and Romanian (20) authors, and all the German publications were written by researchers from the German Democratic Republic. Articles in English were absent: The capitalist world was represented by three French articles (13 pages), one Italian (13) and one Belgian (5). The stable orientation of the journal towards 'friendly' Socialist countries thus remained, the balance between countries changing.

Although some reforms of the Hungarian economic system in 1968 led to a revival of some of the country's traditional links with the West, this was hardly apparent in the international orientation of Földrajzi Közlemények: In the 1970s, 78.3\% of all foreign articles were received from Socialist countries. Only with the political opening-up of the 1980 s was there a thorough scientific change with the proportion of Western scientists' publications increasing to $48.7 \%$ (but still below researchers from Socialist countries: $51.3 \%$ )

\section{Conclusion}

The main goal of this article has been to reveal how geography in Hungary became a victim of foreign imperial interests during the $20^{\text {th }}$ century. We have emphasised not only the discipline's 'inner condition', but also illustrated how it was placed in the broader historical and geographical context of post-war Hungary, and how the Soviet colonisation of the discipline in Hungary was embedded into the tense international context of the Cold War.

The story begins, however, in the late 1910s. As Hungary suffered serious territorial losses after World War I, geography became a highly-respected discipline in the eyes of political authorities because it was regarded as a major tool for the scientific substantiation of claims to territorial revision. In these circumstances, the institutional and financial status of the discipline underwent significant development and its position was strengthened in academic spheres as well as in public education. The interwar period (1918-1939) also witnessed an improvement in the fortunes of Hungarian geography: Human geography was especially open to mainstream Western geographical approaches. Although the country became more and more exposed to the Axis powers in the late 1930s, Hungarian human geography was characterised by a strong French orientation and Hungarian geographers considered German geopolitics totally unacceptable, even during World War II.

These circumstances did not protect the discipline from being stigmatised by the newly-emerging post-war Communist regime. Geography was seen 'guilty' of hav- 
ing served the national-conservative political regime ('fascist' in the Communists' interpretation) during the interwar period. It was an explicit goal of the new system to demolish the 'old' 'reactionary' and 'bourgeois' geography and to set up a new, Marxist-Leninist one following the example of Soviet geography. This 'destructive creation' led to changes in the discipline's institutional background. Some leading personalities of interwar geography were suppressed, others given only limited authority. In their place, a number of 'new geographers' - the most loyal supporters of the Communist regime, but often lacking even a formal university education in geography - were given leading positions in the discipline.

As Ferenc FoDor wrote six decades ago in his lengthy manuscript $A$ magyar földrajztudomány története (The history of Hungarian geography): "What has happened since 1944 is not a history of science but politics and the wrecking and interment of our science. The history of science cannot speak about it yet, but one day it doubtless has to and will do so" (FoDor 1951, p. 285). The Soviet colonisation of the Hungarian geography was undertaken rather rapidly. Its consequences were long-lasting and are still apparent. Confronting and understanding this piece of our unfinished past is likely to be a difficult process and, necessarily, quite a long one. In writing this paper, our aim has been to take the first steps on this long road.

\section{Acknowledgements}

We would like to thank our friends, Márton Czirfusz, Zoltán Gyimesi and Énok OLÁH for the many inspiring talks that we had writing this paper. We are also grateful to Trevor Barnes, Peter Meusburger and especially to Charles Withers for their comments, thoughtful criticism and help on the early versions of the manuscript. Róbert GYőRI appreciates the scholarship of the co-funded International Exchange Programme of the Royal Society of Edinburgh and the Hungarian Academy of Sciences that was taken at the University of Edinburgh. Ferenc GyuRIS would like to acknowledge the University of Heidelberg Graduate Academy for the Landesgraduiertenförderung scholarship. This paper was also supported by the János Bolyai Research Scholarship of the Hungarian Academy of Sciences.

\section{References}

Abella M. (1956), Vita a földrajzi tudományok filozófiai problémáiról [Debate on philosophical challenges of geography]. In: Földrajzi Értesítő, 5, pp. 462-466.

Abella M. (1961), Ankét a településföldrajz helyzetéről és feladatairól [Workshop on the state and tasks of settlement geography]. In: Földrajzi Értesítő, 10, pp. 121-127.

Ablonczy B. (2007), Pál Teleki. The Life of a Controversial Hungarian Politician. Wayne (NJ), Hungarian Studies Publications.

ACzéL G. (1980), A magyar tudomány társadalmi felelősségéről [On social responsibility of Hungarian science]. In: Magyar Tudomány, 141, pp. 161-176. 
Andics E. (1945), Fasizmus és reakció Magyarországon [Fascism and reaction in Hungary]. Budapest, Szikra.

ANON (1954), Vitaülés objektív gazdasági törvényszerúségek feltárásáról [Public debate on revealing objective regularities in economic geography]. In: Földrajzi Értesítő, 3, pp. 779-783.

Antal Z. (2006), Az általános gazdasági földrajz hazai megalapozói: Teleki Pál, Mendöl Tibor és Markos György [The founders of general economic geography in Hungary: Pál Teleki, Tibor Mendöl and György Markos]. In: Bцанó J., Tóтн J. (eds.), Tanulmányok Mendöl Tibor születésének 100. évfordulójára, pp. 22-39. Orosháza - Pécs, A Mendöl Tibor Centenáriumi Év Bizottsága.

Ashcroft B., Griffiths G., Tiffin H. (eds.) (1998), Key Concepts in Post-Colonial Studies. London, Routledge.

Baranskiy N.N. (1956), Economic Geography of the U.S.S.R. Moscow, Foreign Languages Publication House.

BARNES T. (2004), Placing ideas: genius loci, heterotopia and geography's quantitative revolution. In: Progress in Human Geography, 28, pp. 565-595.

BARNES T. (2006), Geographical intelligence: American geographers and research and analysis in the Office of Strategic Services 1941-1945. In: Journal of Historical Geography, 32, pp. 149-168.

BARNES T., FARISH M. (2006), Between regions: science, militarism, and American geography from World War to Cold War. In: Annals of the Association of American Geographers, 94, pp. 807-826.

BERnÁt T. (2004), Emlékezés Markos Györgyre, az iskolateremtő geográfusra halálának 100. évfordulóján [Remembrance of György Markos, the school founder geographer at the $100^{\text {th }}$ anniversary of his death] (sic!). In: Földrajzi Közlemények, 128, pp. 180-182.

Chioni Moore D. (2001), Is the Post in Postcolonial the Post in Post-Soviet? Notes Toward a Global Postcolonial Critique. In: PMLA, 116, pp. 111-128.

Czirfusz M. (2010), A földrajztudományi mező múködése a hatvanas évek két kandidátusi védése alapján [The functioning of the geographical field in the light of two candidate defences of the 1960s]. In: B AJMócy P., Józsa K. (eds.), Geográfus Doktoranduszok X. Országos Konferenciája. Szeged, SZTE TTIK.

Dobrov A.S. (1952), Az imperalizmus védelmének alapvető módszerei a burzsoá gazdasági földrajzban [Basic methods of defending imperialism in bourgeois economic geography]. In: Földrajzi Értesítô, 1, pp. 1-32.

DövÉNYI Z. (2008), Rónai András - vázlatos pályakép [András Rónai - draft career path]. In: Földrajzi Értesító, 57, pp. 9-20.

Enyedi G. (1968), Markos György. In: Földrajzi Értesító, 17,pp. 405-406.

Fodor F. (1924), Magyarország gazdasági földrajza [Economic geography of Hungary]. Budapest, Franklin Társulat.

FoDor F. (1951), A magyar földrajztudomány története [The history of Hungarian geography]. (Manuscript, Budapest, MTA Kézirattár, published by MTA FKI, Budapest 2006).

Gerasimov I.P. (1956), A szovjet geográfia állapota és feladatai a fejlódés mai szakaszában [State and tasks of Soviet geography in the current phase of development]. In: Földrajzi Értesítő, 5, pp. 1-10.

Gerasimov I.P. (1959), A földrajz a Szovjetunióban [Geography in the Soviet Union]. In: Földrajzi Értesító, 8, pp. 406-415.

Gerő E. (1950), A Magyar Tudományos Tanács feladatairól [On the tasks of the Hungarian Scientific Council] (Gerō's speech on the statutory meeting of the Hungarian Scientific Council on $25^{\text {th }}$ February 1949). In: Geró E. (ed.), Harcban a szocialista népgazdaságért, Válogatott beszédek és cikkek 1944-1950, pp. 341-354. Budapest, Szikra. 
GYőRI R. (2001), A magyar gazdaságföldrajz a két világháború között [Hungarian economic geography between the world wars]. In: NEMES NAGY J. (ed.), Geográfia az ezredfordulón, pp. 61-83. Budapest, ELTE TTK RFT.

GYŐRI R. (2007), Dunántúl - valóság vagy fikció? A történeti földrajz bizonyítékai [Transdanubia - reality or fiction? Evidences of historical geography]. In: Limes, 20, pp. 7-22.

GYőri R. (2009), Tibor Mendöl. In: LoRIMER H., Withers C.W.J. (eds.), Geographers (= Biobibliographical Studies, 28), pp. 39-54. London, Continuum.

HaJdú Z. (1998), Changes in the Politico-geographical Position of Hungary in the $20^{\text {th }}$ Century (= Discussion Papers, 22). Pécs, CRS HAS.

HAJdú Z. (2000), A magyar földrajztudomány és a trianoni békeszerződés. 1918-1920 [The Hungarian geography and the Peace Treaty of Trianon, 1918-1920]. In: Kisebbségkutatás, 9, pp. 224-233.

HAJDú Z. (2001), Magyarország közigazgatási földrajza [Administrative geography of Hungary]. Budapest - Pécs, Dialóg Campus.

HAJdú Z. (2006), Fodor Ferenc: a geográfus [Ferenc Fodor: the geographer]. In: Fodor F. (1951), A magyar földrajztudomány története, pp. xi-xlii. (Manuscript, Budapest, MTA Kézirattár, published by MTA FKI, Budapest).

HAJdú Z. (2007), Hungarian researches on the Southeast-European space (the Balkans): continuity, interruption or permanent re-start. In: HAJdú Z., IlLÉs I, RAFFAY Z. (eds.), Southeast Europe: State Borders, Cross-border Relations, Spatial Structures, pp. 10-45. Pécs, CRS HAS.

HoRvÁth G. (2008), Regionális átalakulás Oroszországban [Regional transformation in Russia]. In: HoRváth G. (ed.), Regionális fejlődés és politika az átalakuló Oroszországban, pp. 11-62. Pécs, MTA RKK.

K. L. (1960), Radó Sándor, a Magyar Földrajzi Társaság Társelnöke 60 éves [Sándor Radó, the co-president of the Hungarian Geographical Society is 60 years old]. In: Földrajzi Közlemények, 84, pp. 220-223.

KAPOOR I. (2004), Hyper-self-reflexive development? Spivak on representing the Third World 'Other'. In: Third World Quarterly, 25, pp. 627-647.

KemÉnYFi R. (2006), Egységes magyar államtér alatt egységes kőzetalap: a Tisia-masszívum mítosza [Unitary lithological base beneath unitary Hungarian national space: the myth of Tisia Massive]. In: GYôRi R., HAJdú Z. (eds.), Kárpát-medence: települések, tájak, régiók, térstruktúrák, pp. 418-438. Budapest - Pécs, Dialóg Campus.

Косн F. (1952), A Magyar Földrajzi Társaság újjáalakulása [Re-establishment of the Hungarian Geographical Society]. In: Földrajzi Értesító, 1, pp. 884-887.

Kосн F. (1956), Teleki Pál gazdaságföldrajzi munkásságának bírálata [Criticism on Pál Teleki’s contribution to economic geography]. In: MTA Társadalmi - Történeti Tudományos Osztályának Közleményei, 8, pp. 89-122.

Krasznai Z. (2003), Szakértelem és geopolitika. Földrajztudósok az első világháború után: Emmanuel de Martonne és Teleki Pál [Expertise and geopolitics. Geographers after World War I: Emmanuel de Martonne and Pál Teleki]. In: Horváth Z.K., Lugosi A., SohajDa F. (eds.), Léptékváltó társadalomtörténet (Tanulmányok a 60 éves Benda Gyula tiszteletére), pp. 345-365. Budapest, Hermész Kör - Osiris.

Lenin V.I. (1966), Collected Works, Vol. 31. April-December 1920. Moscow, Progress Publishers.

MARKos G. (1952), A természeti földrajzi környezet hatása különböző társadalmi formák között [The implication of physical geographical environment among various social forms]. In: Földrajzi Értesítő, 1, pp. 271-287.

Markos G. (1955), Reflexiók egy beszámolóhoz. (A földrajzi tudományok rendszertani alapjairól) [Reflections on a report. On the taxonomical basis of geographical sciences]. In: Földrajzi Közlemények, 79, pp. 359-365. 
Marosi S. (2001), Az MTA Földrajztudományi Kutatóintézetének 50 éve [Fifty years of the Geographical Research Institute of HAS]. Budapest, MTA FKI.

Marosi S. (2006), Bulla Béla emlékezete [Homage to Béla Bulla]. In: Földrajzi Közlemények, 130 , pp. 103-110.

Marx K. (1949), A tôke [Capital]. Budapest, Szikra.

McEwan C. (2009), Postcolonialism and Development. London - New York, Routledge.

Mendöl T. (1954), A szocialista településföldrajz problémái [Challenges of Socialist urban geography] In: MTA Társadalmi - Történeti Tudományos Osztályának Közleményei, pp. 599-627.

Niedermaier H. (2009), Marxistische Theorie. In: Kneer G., Schroer M. (eds.), Handbuch Soziologische Theorien, pp. 221-236. Wiesbaden, VS Verlag für Sozialwissenschaften.

PAPP-VÁRY Á. (1998), Radó Sándor (1899-1981). In: Földrajzi Közlemények, 122, pp. 99-101. Péteri G. (1998), Academia and State Socialism. New York, Columbia University Press.

PRoBÁLD F. (2001), Száz esztendeje született a Regionális Földrajzi Tanszék alapító professzora: Koch Ferenc [Ferenc Koch, the founding professor of the Department of Regional Geography, was born 100 years ago]. In: NeMES NAGY J. (ed.), Geográfia az ezredfordulón, pp. 85-88. Budapest, ELTE TTK RFT.

RADó S. (1957a), Adatok a szovjet gazdaságföldrajz történetéhez [Some data on the history of Soviet economic geography]. In: Földrajzi Értesítő, 6, pp. 490-492.

RADó S. (1957b), A szovjet földrajztudomány 40 éve [Fourty years of Soviet geography]. In: Földrajzi Közlemények, 81, pp. 305-318.

RADÓ S. (1962), A kommunizmus építése és a földrajzi tudományok [The construction of Communism and geographical sciences]. In: Földrajzi Közlemények, 86, pp. 225-232.

SAID E. (1993), Culture and Imperialism. London, Vintage Books.

SAUSHKin J.G. (1954), A Szovjetunió gazdasági földrajzának alapvető kérdései [Basic issues of economic geography of the Soviet Union]. In: Földrajzi Értesítő, 3, pp. 86-100.

Saushrin J.G. (1962), Economic Geography in the U.S.S.R. In: Economic Geography, 38, pp. 28-37.

Stalin J.V. (1950), A leninizmus kérdései [Issues of Leninism]. Budapest, Szikra.

Stenning A., Hörschelmann K. (2008), History, geography and difference in the post-socialist world: or do we still need post-socialism? In: Antipode, 40, pp. 312-335.

SÜLI-ZAKAR I. (2008), Kádár László és a „társadalomföldrajz” [László Kádár and »human geography «]. In: Szabó J., Demeter G. (eds.), Geographia generalis et specialis (Tanulmányok a Kádár László születésének 100. évfordulóján rendezett tudományos konferenciára), pp. 27-34. Debrecen, Kossuth Egyetemi Kiadó.

Tatai Z. (2004), Markos György. In: Comitatus, 14, pp. 71-80.

Thомаs L. (1968), Alexander Rado. In: Studies in Intelligence, 12, pp. 41-61.

TimÁr J. (2009), Communist and Post-Communist Geographies. In: Kitchin R., Thrift N. (eds.), International Encyclopedia of Human Geography, Vol. 1, pp. 214-220. Oxford, Elsevier.

Trom A. (2006), A teljes Dóra jelenti margójára [To the margin of the whole Codename Dora]. In: RADó S., Dóra jelenti (Ötödik, bővített, javított és átszerkesztett kiadás), pp. 5-15. Budapest, Kossuth Kiadó. 